\title{
Assessment of microcystins in surface water and irrigated vegetables in Kwaru stream, Hayin Danmani, Kaduna-Nigeria
}

Halima Abdullahi

Ahmadu Bello University

Yahuza Tanimu

Ahmadu Bello University

Suwebat Ayanronke Akinyemi

Osun State University

Maria do Carmo Bittencourt-Oliveira

University of Sao Paulo: Universidade de Sao Paulo

Mathias Ahii Chia ( $\square$ chia28us@yahoo.com )

University of Sao Paulo https://orcid.org/0000-0002-3549-5475

\section{Research Article}

Keywords: irrigation, vegetables, microcystins, cyanobacteria, cyanotoxins, stream water

Posted Date: February 9th, 2022

DOI: https://doi.org/10.21203/rs.3.rs-1253998/v1

License: (a) (i) This work is licensed under a Creative Commons Attribution 4.0 International License. Read Full License 


\section{Abstract}

Microcystins (MCs) are hepatotoxic secondary metabolites produced by several genera of cyanobacteria. Human exposure routes include drinking contaminated water and consuming contaminated fish, vegetables, crops, and even food supplements that contain cyanotoxin. This study investigated the presence of MCs in a stream with a long history of use as a source of water for irrigation farming. To establish the risk of lack of monitoring programs, we studied MCs contamination of irrigated vegetables. Toxin levels in the water were generally $<0.05 \mathrm{\mu g} \mathrm{L}^{-1}$ in all the investigated stations. Total microcystin concentrations in spinach $\left(0.306 \mu \mathrm{g} \mathrm{Kg}^{-1}\right.$ upstream and $0.217 \mu \mathrm{g} \mathrm{Kg}^{-1}$ downstream), lettuce $(0.085 \mu \mathrm{g} \mathrm{Kg}$ 1 upstream and $0.462 \mu \mathrm{g} \mathrm{Kg}^{-1}$ downstream), carrot $\left(0.050 \mu \mathrm{g} \mathrm{Kg}^{-1}\right.$ downstream and $0.116 \mu \mathrm{g} \mathrm{Kg}^{-1}$ downstream), cabbage $\left(0.014 \mu \mathrm{g} \mathrm{Kg}^{-1}\right.$ upstream and $0.031 \mu \mathrm{g} \mathrm{Kg}^{-1}$ downstream), tomatoes $\left(0.233 \mu \mathrm{g} \mathrm{Kg}^{-}\right.$

${ }^{1}$ upstream) and bitter leaf $\left(0.460 \mathrm{\mu g} \mathrm{Kg}^{-1}\right.$ upstream and $0.050 \mu \mathrm{g} \mathrm{Kg}^{-1}$ downstream) collected in March were higher than the levels detected in samples of the same vegetables collected in April. These results highlight Nigeria's severe public health problem, especially in regions with long dry season spells. The level of MCs contamination of irrigated vegetables implies a potential for chronic exposure and associated health challenges.

\section{Introduction}

Cyanobacteria, also known as blue-green algae, are microorganisms and autotrophic organisms which are primary producers in aquatic systems, hence categorized as algae (Picardo et al. 2019). Some strains have rich chemistry because they produce various bioactive compounds with varying properties (EI Gamal 2010; Picardo et al. 2019) Meanwhile, other forms yield a variety of toxic and possibly harmful compounds, in the form of secondary metabolites, termed cyanotoxins, attributed as one of the most important groups of natural toxins (Otten and Paerl 2015; Kimambo et al. 2019; Griffith and Gobler 2020)

Microcystins are hepatotoxins primarily found in marine and freshwaters worldwide (Liu et al. 2018; Wei et al. 2020). MCs are heat-stable and water-soluble cyclic peptides containing seven amino acids, and over 279 variants of the cyanotoxin have been identified to date (Bouaïcha et al. 2019). They are toxic to humans, domestic animals, livestock, and aquatic organisms because they are potent inhibitors of phosphatases of the serine/threonine-protein 1 (PP1) and 2A (PP2A) as well as disruptors of intracellular homeostasis (Fontanillo and Köhn 2018; Massey et al. 2018; Zhao et al. 2021) The inhibition of these phosphatases disarranges cell cytoskeleton, causes cell death, leads to intrahepatic haemorrhage, and sometimes kills exposed organisms (Carmichael 1992)

MCs are the most ubiquitous and commonly occurring cyanotoxins in freshwater systems (Pham and Utsumi 2018). Microcystins can get into the mammalian body by consuming contaminated water, food and algal dietary supplements, body contact, hemodialysis, and inhalation to a lesser extent (Massey et al. 2018). Due to MC toxic consequences, the International Agency for Research on Cancer (IARC) has categorized this toxin as a possible carcinogen (Cancer 2010). To lessen and prevent MC health hazards, the World Health Organization (WHO) recommended a provisional $1 \mu \mathrm{g} / \mathrm{L} \mathrm{MC}$ guideline for drinking water 
quality (WHO 1998). (Duy et al. 2000) and (Falconer and Humpage 2005) postulated that MCs are carcinogenic because they promote liver tumors and emerging evidence from China and elsewhere (Ueno et al. 1996; Humpage et al. 2000).

Plant irrigation with MCs contaminated water is an important pathway for human exposure when contaminated food is consumed (Chen et al. 2004). The ability of MCs to bioaccumulate in plant and animal tissues is responsible for the risk involved in consuming contaminated food. Several laboratory and field evidence shows that several vegetables irrigated with MCs contaminated water (dissolved MCs) and toxin-producing strains of cyanobacteria (particulate MCs) bioaccumulate substantial amounts of this cyanotoxin (Crush et al. 2008; Hereman and Bittencourt-Oliveira 2012). The bioaccumulation of MCs in plant and animal tissues led the World Health Organization (WHO) to recommend a maximum daily intake of $0.04 \mu \mathrm{g} \mathrm{Kg}^{-1}$ of body mass (WHO 1998).

Irrigation of vegetables in Northern Nigeria is usually practiced due to the uneven distribution and sometimes inadequate rainfall for vegetable production. The eutrophication and formation of cyanobacteria blooms in inland waters such as seasonal streams, rivers, and lakes make them unfit for irrigation purposes because of the frequent detection of cyanotoxins (Chia et al. 2009, 2015). As there are no monitoring programs and management for cyanobacteria blooms and cyanotoxins in most developing countries, investigations highlighting the presence, levels, and the risk of contamination and consumption of irrigated crops (Peuthert et al. 2015; Cordeiro-Araújo et al. 2016; do Carmo BittencourtOliveira et al. 2016). The investigated area and stream, Kwaru stream, represents a vital ecosystem type that has been poorly investigated. Most studies in Africa and other tropical regions focus on large water supply reservoirs, while less attention has been given to streams and rivers. Therefore, the study aimed to investigate the level of MCs in surface water and some irrigated vegetables at Kwaru stream, Hayin DanMani Kaduna, Nigeria. We investigated this ecosystem to demonstrate their importance and contributions to MCs as a human exposure pathway.

\section{Materials And Methods}

\section{Study Area}

The study was carried out at Kwaru stream, Hayin Dan-Mani, Kaduna. Kwaru stream is an urban stream that is impacted by many anthropogenic activities such as dumping domestic solid wastes, wastewater from residential areas, car wash, and it is an important source of drinking water for cattle and diverse irrigated crops in the dry season. Kaduna is located in the northern guinea savanna region of Nigeria, and it is characterized by two distinct seasons in the year; the dry and rainy seasons. The dry season runs from November to April and is characterized by cold and dry conditions, and the harmattan wind blows from the northeast toward the southwest. On the other hand, the rainy season, which runs from May to early October, is depicted by warm and humid conditions with the wind blowing from the southwest towards the northeast. The average monthly temperature of the region is between $26^{\circ} \mathrm{C}$ and $34^{\circ} \mathrm{C}$ (Bununu et al. 2015). Five sampling stations were selected along the irrigated stretch of Kwaru Stream based on 
the activities along the stream's catchment. Station $1\left(10^{\circ} 32^{\prime} 41.5^{\prime \prime} \mathrm{N}, 007^{\circ} 24^{\prime} 26.5^{\prime \prime} \mathrm{E}\right)$ is upstream and receives run-off mainly from the farms upstream stream. Station $2\left(10^{\circ} 32^{\prime} 36.0^{\prime \prime} \mathrm{N}, 007^{\circ} 24^{\prime} 25.5^{\prime \prime} \mathrm{E}\right)$ is characterized by irrigation farming, dumping and burning waste. Station $3\left(10^{\circ} 32^{\prime} 21.6^{\prime \prime} \mathrm{N}, 007^{\circ} 24^{\prime} 22.6^{\prime \prime} \mathrm{E}\right)$ is depicted by dumping wastes such as polythene bags, waste food, and cattle grazing and watering. The activities in station $4\left(10^{\circ} 32^{\prime} 13.0^{\prime \prime} \mathrm{N}, 007^{\circ} 24^{\prime} 16.4^{\prime \prime} \mathrm{E}\right)$ include car and upholstery wash points, irrigation water pump sites, and open human and cattle defecation. In station 5 ( $\left.10^{\circ} 32^{\prime} 15.5^{\prime \prime} \mathrm{N} 007^{\circ} 24^{\prime} 12.3^{\prime \prime} \mathrm{E}\right)$, we found an inflow of wastewater from residential and agricultural areas.

\section{Water and vegetable sample collection}

Surface water of Kwaru stream and vegetable samples were collected in March and April 2019, representing the driest months and the peak of the dry season. These months also coincide with when most irrigated vegetables attain harvest age and size. The samples of Leafy vegetables collected included Amaranthus hybridus (spinach), Brassica oleracea (cabbage), Lactuca sativa (lettuce), Hibiscus cannabinus (kenaf), and Vernonia amygdalina (bitter leaf). Fruit vegetable samples included Daucus carota (carrot) and Lycopersicum esculentum (tomatoes). The samples were collected in triplicates upstream (stations 1, 2 and 3) and downstream (stations 4 and 5). Sample identification was authenticated at the Herbarium of the Department of Botany, Ahmadu Bello University, Zaria, Nigeria.

\section{Microcystins Analysis}

Aliquots $(5 \mathrm{ml})$ of water samples were frozen and thawed severally to break the microcystins cells (Chia and Kwaghe 2015). Furthermore, cellular contents were extracted in $75 \%$ methanol following (Chia and Kwaghe 2015). Next, vegetable samples were rinsed with tap water followed by distilled water. Then, $2 \mathrm{~g}$ of each sample was cut with a razor blade, weighed and homogenized using a mortar and pestle in $80 \%$ methanol to obtain a homogenous mixture (Díez-Quijada et al. 2018). The choice of $80 \%$ methanol was to dissolve the intracellular toxins (Turner et al. 2018). Finally, the homogenate was centrifuged at 2000 rpm (10 minutes), and the supernatant was extracted and preserved at $-40^{\circ} \mathrm{C}$ until ready for analysis.

Extracts were subjected to microcystins analysis using a 96 well Abraxis Microcystins-ADDA EnzymeLinked Immunosorbent Assay (ELISA) kit, following the manufacturer's instructions. The absorbance of the colour reaction at the end of the ELISA procedure was read at $450 \mathrm{~nm}$ in a Bio-Rad iMark ${ }^{\mathrm{TM}}$ Microplate reader (Bio-Rad Laboratories, Inc., Hercules CA, USA), and the concentrations expressed per cell quota of potential microcystins producing species (Chia et al. 2019).

\section{Data Analyses}

The statistical significance of changes in microcystins accumulated in vegetables and total microcystins in water was determined using analysis of variance (ANOVA). When significant differences existed, the 
Tukey's post-hoc test was used to perform a multiple comparison. The significance level for all analyses was set at $p$ 0.05. The total daily intake (TDI) limit of $0.04 \mathrm{~g} \mathrm{~kg}-1$ body weight, determined by the World Health Organization, was used to estimate the risk of eating contaminated vegetables(WHO 2011). The first part of the analysis was based on the premise that an adult of $60 \mathrm{~kg}$ consumes at least $40 \mathrm{~g}$ of vegetable per day and a microcystin content threshold of $60 \mathrm{~g} \mathrm{~kg}-1$ in vegetable tissues.

\section{$T D I_{\text {fish }}=M C s_{40 g^{-1}} / B M$ Equation 1}

Where $\mathrm{MCs}_{40 \mathrm{~g}}{ }^{-1}$ is the concentration of MCs per $40 \mathrm{~g}$ of vegetables and BM is body mass of an adult weighing at least $60 \mathrm{~kg}$.

The monthly and seasonal risks of eating microcystins-contaminated vegetables from study area were predicted using the hierarchical/multilevel modeling method. Equation 2 shows the model that was generated:

\section{$M C s_{i j} \sim\left(\beta_{0}+\beta_{j}, \sigma_{0}^{2}\right), \beta_{j} \sim N\left(0, \sigma_{1}^{2}\right)$ Equation 2}

Note: The veggies are represented by the MCs. MCs represents the content of the ith observation from the jth group (stream location or month), $\beta_{0}$ represents the overall mean or intercept, $\beta_{j}$ represents the grouptype mean, $\sigma_{0}^{2} \&$ represents within-group variance, and represents between-group variance. The Imer function of the Ime4 package (Bates 2010) of R was used to perform hierarchical modeling, with restricted maximum likelihood (REML) set to FALSE. Analysis of variance with the ranova function of the jtools package of $R$ was used to determine the significance of the various multilevel tests. Using cumulative distribution functions, the monthly and stream location risks of consuming infected veggies from the analyzed water source were also demonstrated (CDF).

Using Pearson's correlation coefficient and the $\mathrm{R}$ base stats function, the correlation between vegetable tissue bound microcystins and cyanobacterial cell bound microcystins was found. R (https://www.rproject.org) software for macOS was used for all statistical studies.

\section{Results}

\section{Total microcystin concentrations in water}

Total microcystin concentration in water in the five different stations in March and April varied significantly (Fig. 1). The highest concentration was observed in April in station $4\left(0.246 \mu \mathrm{g} \mathrm{L}^{-1}\right)$, while the lowest was recorded in March $\left(0.040 \mu \mathrm{g} \mathrm{L}^{-1}\right)$ in station 2. There was no specific trend in total MCs variation in March. Regardless of the sampling period or sampling station, MC concentrations were lower than $1.0 \mu \mathrm{g} \mathrm{L}^{-1}$, the maximum permissible levels recommended by the WHO. 


\section{Total microcystins content of vegetables}

On a general note, higher $\mathrm{MC}$ levels occurred in vegetables sampled in March than those collected in April (Fig. 2). Per sampling location, the levels of MCs bioaccumulated in the vegetables varied depending on the vegetable. In March upstream, bitter leaf had the highest bioaccumulated microcystins concentration $\left(0.460 \mu \mathrm{g} \mathrm{Kg}^{-1}\right)$, while cabbage had the lowest $\left(0.01 \mu \mathrm{g} \mathrm{Kg}^{-1}\right)$. Downstream, lettuce $\left(0.462 \mu \mathrm{g} \mathrm{Kg}^{-1}\right) \mathrm{had}$ the highest MCs concentration, while cabbage $\left(0.030 \mathrm{ug} \mathrm{Kg}^{-1}\right)$ had the lowest concentration. In April, the highest bioaccumulated microcystins level downstream occurred in spinach $\left(0.217 \mu \mathrm{g} \mathrm{Kg}^{-1}\right)$, while the lowest was found in cabbage $\left(0.0007 \mu \mathrm{g} \mathrm{Kg}^{-1}\right)$. In April, kenaf $\left(0.021 \mu \mathrm{g} \mathrm{Kg}^{-1}\right)$ had the highest upstream concentration, while the lowest was in cabbage $\left(0.0017 \mu \mathrm{g} \mathrm{Kg}^{-1}\right)$. There were no detectable levels of MCs in lettuce.

\section{Total Daily Intake (TDI) of microcystins contaminated vegetables and cumulative distribution of tissue bound microcystins}

As MCs TDI calculations are based on bioaccumulated in edible parts of vegetables, higher TDIs were found in March than in April (Fig. 3). Spinach had the highest MCs TDI by an adult (TDIA) and a child (TDIC) throughout the present study (Fig. 3). Also, spinach, lettuce, tomato, bitter leaf and carrot had TDIA and TDIC values greater than $0.04 \mathrm{\mu g} \mathrm{Kg}^{-1}$, the limit set by the WHO. Contrarily, in April, only spinach had TDIA and TDIC values greater than $0.04 \mu \mathrm{g} \mathrm{Kg}^{-1}$.

The CDFs of MCs in water showed marked variations in the risk of consuming untreated water from the stream (Fig. 4). The risk of drinking less than $0.1 \mu \mathrm{g} \mathrm{L}^{-1} \mathrm{MC}$ contaminated water was more than $75 \%$ across most stations (Fig. 4a). On the other hand, drinking water from station 4 posed the highest risk to humans and animals because more than $40 \%$ of the samples collected from the station had MC levels more than $0.1 \mu \mathrm{g} \mathrm{L}^{-1}$. In line with the levels of MCs detected in water, the lowest risk of drinking contaminated water was in station 4 . Also, there was more than a $75 \%$ percent risk of consuming water containing more than $0.1 \mathrm{\mu g} \mathrm{L}^{-1} \mathrm{MC}$ in April, whereas the risk of consuming less than this amount was recorded in March (Fig. 4b).

The risk of consuming $\mathrm{MC}$ contaminated vegetables was not significantly different in vegetables irrigated upstream and downstream (Fig. 5a). Regardless of the collection point of vegetables, the chance of consuming vegetables containing more than $0.1 \mathrm{\mu g} \mathrm{g}^{-1} \mathrm{MC}$ was ca. $30 \%$. Unlike the case of drinking MC contaminated water, where the risk was higher in April, in terms of consuming contaminated vegetables, the risk was highest in March than in April (Fig. 5b). Specifically, there was a less than $10 \%$ chance of consuming vegetables containing more than $0.1 \mathrm{\mu g} \mathrm{g}^{-1} \mathrm{MC}$ in April, whereas the reverse was observed in March. More than $50 \%$ chance of consuming vegetables containing more than $0.1 \mathrm{\mu g} \mathrm{g}^{-1} \mathrm{MC}$ was observed in March, indicating substantially different risk levels between the months. The CDFs of the 
investigated vegetables showed distinct differences, showing that risk differs between them (Fig. 5c). Specifically, consuming vegetables such as Kenaf and Cabbage posed the lowest risks, followed by Bitter

leaf and Carrot. The vegetables with the highest risk of exposure to $\mathrm{MC}$ levels greater than $0.1 \mu \mathrm{g} \mathrm{g}^{-1} \mathrm{MC}$ were Spinach, Tomatoes, and Lettuce (Fig. 5c).

\section{Discussion}

\section{Microcystins concentration in stream water}

Most developed countries recognize the risk associated with the excessive proliferation of cyanobacteria and cyanotoxins, while the reverse is the case for most developing countries. Sadly, global climate change and eutrophication of aquatic ecosystems that promote the excessive proliferation of cyanobacteria and cyanotoxins are independent of the economic status of any country and continue to pose significant risks to humans and wildlife. Therefore, the increased occurrence of MCs in aquatic ecosystems and the contamination of irrigated crops poses currently unquantifiable health risks, particularly in developing countries due to a lack of data. The present study results demonstrate the need to generate data from tropical developing countries where conditions are highly suitable for the formation of harmful cyanobacterial blooms. We found detectable levels of MCs in the Kwaru stream with concentrations peaking at the end of the dry season, which is in line with generally reported changes in water quality, weather and cyanotoxins content in Northern Nigeria (Chia et al. 2009; Chia and Kwaghe 2015). Specifically, these changes could be attributed to increased daytime temperatures, reduced water levels, increased nutrients and solar irradiation, favouring the proliferation of cyanobacteria and the production of cyanotoxins like microcystins (Mohamed et al. 2020; Chia et al. 2021)

There is a general water scarcity problem in several developing tropical countries, and northern Nigeria is no exception. This information is critical because people around the catchment of water bodies like Kwaru stream drink the water without prior treatment. Fortunately, the detected levels of total MCs in the present study were lower than the recommended (WHO) guideline value of $1.00 \mathrm{\mu g} \mathrm{L}^{-1}$ for drinking water. However, there were marked differences between the risk of exposure to MCs dependent on the station and the month of water collection. These changes can be linked to the differences in anthropogenic activities along the stream's catchment.

\section{Microcystins content in vegetables}

There were marked differences in the amount of MCs bioaccumulated in irrigated vegetables. These differences are dependent on the levels of MCs in the environment, prevailing environmental conditions, species of vegetable, nature and size of their leaves, and their physiological and biochemical adaptations to the presence of MCs (Chia et al. 2019) For example, higher evapotranspiration rates taking place on leave surfaces than other organs not directly exposed to solar irradiation result in substantial variations in the concentrations of MCs bioaccumulated by plants (Constable and Rawson, 1980). The present 
study's findings collaborate with those of (Chia et al. 2019), who observed higher MC in the leaves of irrigated vegetables than other plant parts. Also, (Mohamed and Al Shehri 2009) and (Chia et al. 2019) found the highest levels of MCs in Amaranthus hybridus (spinach) compared to other irrigated vegetables.

Furthermore, (Crush et al. 2008) demonstrated that higher concentrations of MCs were detected in Lactiva sativa and Trifolium repens with broader leaves than in Brassica napus and Lolium perenne with smaller leaves. This contrasts to (Machado et al. 2017) that detected MC-LR in carrots at $5 \mu \mathrm{gg}^{-1}$ fresh weights, where the root is the edible portion. Finally, it is essential to note that fruits or vegetables like tomatoes had substantially high levels of MCs comparable to other broad leave vegetables, an indication that fruits.

In April, only spinach had a high MC concentration compared to other vegetables. Lower MCs' bioaccumulated levels in all the vegetables in April negatively correlated with the highest MCs levels found in the water in the same month. This observation implies that when the length of irrigation, which leads to bioaccumulation of significant amounts in vegetable tissues, is not taken into account, having low MCs levels in water does not necessarily imply minimal risk. Previously, we showed that microcystin congeners vary in their bioaccumulation rates. The bioaccumulation and depuration of MC-LR depend on its saturation concentrations, irrigation duration, plant species and exposure concentration (CordeiroAraújo et al. 2016; do Carmo Bittencourt-Oliveira et al. 2016). Also, the differences observed in the MC content of the investigated vegetables are not surprising as plants have different physiological, biochemical and morphological adaptations that determine the rate at which they uptake and bioaccumulate MCs (Cordeiro-Araújo et al. 2016; do Carmo Bittencourt-Oliveira et al. 2016). Plants also differ in the rates at which they can excrete or depurate MCs and chemically detoxify MCs with antioxidant enzymes (Cordeiro-Araújo et al. 2016). This difference may also account for variations in bioaccumulated MCs in the investigated vegetables.

\section{Total daily intake (TDI) of MCs by humans (adult/child) and risk assessment}

The concentration of MCs in vegetable tissues is usually directly proportional to TDI by humans (Chia et al. 2019). Therefore, higher concentrations of MCs in vegetables resulted in higher TDI and risks by adults and children in the present study. Based on our findings, cabbage (March and April), lettuce (April), carrot (April), bitter leaf (April), tomatoes (April) and kenaf (April) posed no significant acute and chronic risk to humans since the TDI did not exceed the TDI limit set by WHO ( $0.04 \mu \mathrm{g}$ per kg body weight per day). However, the TDI of MC in spinach in March and April and lettuce, carrot, bitter leaf and tomato in March exceeded the TDI limit. Thus, the risk of exposure to MCs in highest in March as indicated by the CDF. While the risk may appear to be higher in March than April, the chance of consuming high levels of MCs is dependent on the vegetable consumed. This outcome agrees with (Chia et al. 2019) findings that irrigated vegetables in northern Nigeria have very high levels of microcystins. The result is also in line 
with previous studies indicating MCs accumulate differentially in various crops irrigated with water contaminated with blue-green algae or MCs (Cordeiro-Araújo et al. 2016; do Carmo Bittencourt-Oliveira et al. 2016; Machado et al. 2017). According to Wood et al. (2004), the WHO's maximum daily intake of MCLR is a suggested limit for healthy adults, meaning that children, the elderly, and sensitive/unhealthy people are more susceptible to the adverse effects of MC consumption. Thus, lower TDI than the WHO recommended levels may not necessarily mean lower risk as vulnerable and unhealthy people may suffer severe ailments post-exposure to MC via this exposure route.

The human health risks from TDI of MCs are plant-specific (Cordeiro-Araújo et al. 2016) and proportional to the degree and rate of bioaccumulation (Crush et al. 2008). Leafy vegetables, especially spinach and lettuce, showed the highest health risk among the various vegetables. Unfortunately, spinach and lettuce are among the most consumed vegetables worldwide, emphasizing the gravity of potential long term health challenges (Zhang et al. 2010). Likewise, many studies have shown that MC-LR is resistant to heat, being stable at temperatures as high as $300^{\circ} \mathrm{C}$ (Bruno et al. 2012)

\section{Conclusion}

Our study revealed that having low MCs levels in water does not necessarily translate to low risk when considerations are not given to the duration of irrigation that leads to bioaccumulation of substantial amounts in vegetable tissues. Specifically, total MCs in water during the months in all the stations were lower than the recommended (WHO) guideline value of $1.00 \mu \mathrm{g} \mathrm{L}^{-1}$ for drinking water. Also, the detected levels of MCs in irrigated vegetables were high, leading to higher TDIs than the $0.04 \mathrm{ug} \mathrm{kg}^{-1}$ body weight by the WHO in March. This study demonstrates the need to develop management strategies for MCs in water bodies used for irrigation farming and the need to screen crops or vegetables harvested from farms before human consumption in developing tropical countries. In addition, consumer education must be encouraged and aggressively pursued to ensure they understand the consequences of MCs contamination of drinking water and irrigated vegetables.

\section{Declarations}

\section{Ethical Approval}

The study did not require ethical clearance because it is did not involve human subjects.

\section{Consent to Participate}

The study did not require a consent to participate because it is did not involve human subjects.

\section{Consent to Publish}

The study was not a case study requiring a consent to publish from subjects. .

\section{Funding}


The authors declare that no funds, grants, or other support were received during the preparation of this manuscript.

\section{Competing Interests}

The authors have no relevant financial or non-financial interests to disclose.

\section{Author Contributions}

All authors contributed to the study conception and design. Material preparation, data collection and analysis were performed by Halima Abdullahi, Suwebat Ayanronke Akinyemi, Maria do Carmo BittencourtOliveira, Yahuza Tanimu, and Mathias Ahii Chia. The first draft of the manuscript was written by Halima Abdullahi and all authors commented on previous versions of the manuscript. All authors read and approved the final manuscript.

\section{Availability of data and materials}

The datasets generated during and/or analysed during the current study are available from the corresponding author on reasonable request.

\section{References}

1. Bouaïcha N, Miles CO, Beach DG et al (2019) Structural diversity, characterization and toxicology of microcystins. Toxins (Basel) 11:714

2. Bruno M, Gallo P, Messineo V, Melchiorre S (2012) Health risk associated with microcystin presence in the environment: the Case of an Italian Lake (Lake Vico, Central Italy). Int J Env Prot 2:34-41

3. Bununu YA, Ludin ANM, Hosni N (2015) City profile: Kaduna. Cities 49:53-65

4. Cancer IA for R on (2010) Ingested nitrate and nitrite, and cyanobacterial peptide toxins. IARC Monogr Eval Carcinog risks to humans 94

5. Carmichael WW (1992) Cyanobacteria secondary metabolites-the cyanotoxins. J Appl Bacteriol 72:445-459

6. Chen J, Song L, Dai J et al (2004) Effects of microcystins on the growth and the activity of superoxide dismutase and peroxidase of rape (Brassica napus L.) and rice (Oryza sativa L.). Toxicon 43:393-400

7. Chia AM, Oniye SJ, Ladan Z et al (2009) A survey for the presence of microcystins in aquaculture ponds in Zaria, Northern-Nigeria: Possible public health implication. African J Biotechnol 8:62826289. https://doi.org/10.5897/AJB09.1263

8. Chia MA, Abdulwahab R, Ameh I et al (2021) Farmed tilapia as an exposure route to microcystins in Zaria-Nigeria: A seasonal investigation. Environ Pollut 271:116366

9. Chia MA, Auta ZZ, Esson AE et al (2019) Assessment of microcystin contamination of Amaranthus hybridus, Brassica oleracea, and Lactuca sativa sold in markets: a case study of Zaria, Nigeria. 
Environ Monit Assess 191:569. https://doi.org/10.1007/s10661-019-7725-4

10. Chia MA, Cordeiro-Araujo MK, Bittencourt-Oliveira C (2015) M Growth and antioxidant response oficrocystis aeruginosa (Cyanobacteria) exposed to anatoxin-a. Harmful Algae 49:135-146

11. Chia MA, Kwaghe MJ (2015) Microcystins contamination of surface water supply sources in ZariaNigeria. Environ Monit Assess 187:1-12

12. Cordeiro-Araújo MK, Chia MA, de Arruda-Neto T et al (2016) Microcystin-LR bioaccumulation and depuration kinetics in lettuce and arugula: Human health risk assessment. Sci Total Environ 566:1379-1386

13. Crush JR, Briggs LR, Sprosen JM, Nichols SN (2008) Effect of irrigation with lake water containing microcystins on microcystin content and growth of ryegrass, clover, rape, and lettuce. Environ Toxicol An Int J 23:246-252

14. Díez-Quijada L, Guzmán-Guillén R, Prieto Ortega Al et al (2018) New method for simultaneous determination of microcystins and cylindrospermopsin in vegetable matrices by SPE-UPLC-MS/MS. Toxins (Basel) 10:406

15. do Bittencourt-Oliveira C, Cordeiro-Araújo M, Chia MK et al (2016) Lettuce irrigated with contaminated water: Photosynthetic effects, antioxidative response and bioaccumulation of microcystin congeners. Ecotoxicol Environ Saf 128:83-90

16. Duy TN, Lam PKS, Shaw GR, Connell DW (2000) Toxicology and risk assessment of freshwater cyanobacterial (blue-green algal) toxins in water.Rev Environ Contam Toxicol113-185

17. El Gamal AA (2010) Biological importance of marine algae. Saudi Pharm J 18:1-25

18. Falconer IR, Humpage AR (2005) Health risk assessment of cyanobacterial (blue-green algal) toxins in drinking water. Int J Environ Res Public Health 2:43-50

19. Fontanillo M, Köhn M (2018) Microcystins: Synthesis and structure-activity relationship studies toward PP1 and PP2A. Bioorg Med Chem 26:1118-1126

20. Griffith AW, Gobler CJ (2020) Harmful algal blooms: a climate change co-stressor in marine and freshwater ecosystems. Harmful Algae 91:101590

21. Hereman TC, Bittencourt-Oliveira M (2012) do C Bioaccumulation of microcystins in lettuce. J Phycol 48:1535-1537

22. Humpage AR, Hardy SJ, Moore EJ et al (2000) Microcystins (cyanobacterial toxins) in drinking water enhance the growth of aberrant crypt foci in the mouse colon. J Toxicol Environ Heal Part A 61:155165

23. Kimambo ON, Gumbo JR, Chikoore H (2019) The occurrence of cyanobacteria blooms in freshwater ecosystems and their link with hydro-meteorological and environmental variations in Tanzania. Heliyon 5:e01312

24. Liu P, Wei J, Yang K et al (2018) Isolation, molecular identification, and characterization of a unique toxic cyanobacterium Microcystis sp. found in Hunan Province, China. J Toxicol Environ Heal part A $81: 1142-1149$ 
25. Machado J, Azevedo J, Freitas M et al (2017) Analysis of the use of microcystin-contaminated water in the growth and nutritional quality of the root-vegetable, Daucus carota. Environ Sci Pollut Res 24:752-764

26. Massey IY, Yang F, Ding Z et al (2018) Exposure routes and health effects of microcystins on animals and humans: A mini-review. Toxicon 151:156-162

27. Mohamed Z, Ahmed Z, Bakr A et al (2020) Detection of free and bound microcystins in tilapia fish from Egyptian fishpond farms and its related public health risk assessment. J Consum Prot Food Saf 15:37-47

28. Mohamed ZA, Al Shehri AM (2009) Microcystins in groundwater wells and their accumulation in vegetable plants irrigated with contaminated waters in Saudi Arabia. J Hazard Mater 172:310-315

29. Otten TG, Paerl HW (2015) Health effects of toxic cyanobacteria in US drinking and recreational waters: our current understanding and proposed direction. Curr Environ Heal reports 2:75-84

30. Peuthert A, Kun L, Baik S, Pflugmacher S (2015) Transfer of cyanobacterial toxins into edible plants via irrigation with Lake water-A Chinese case study. Aperito J Aquat Mar Ecosys 1:1-7

31. Pham T-L, Utsumi M (2018) An overview of the accumulation of microcystins in aquatic ecosystems. J Environ Manage 213:520-529

32. Picardo M, Filatova D, Nunez O, Farré M (2019) Recent advances in the detection of natural toxins in freshwater environments. TrAC Trends Anal Chem 112:75-86

33. Turner AD, Dhanji-Rapkova M, O'Neill A et al (2018) Analysis of microcystins in cyanobacterial blooms from freshwater bodies in England. Toxins (Basel) 10:39

34. Ueno Y, Nagata S, Tsutsumi T et al (1996) Detection of microcystins, a blue-green algal hepatotoxin, in drinking water sampled in Haimen and Fusui, endemic areas of primary liver cancer in China, by highly sensitive immunoassay. Carcinogenesis 17:1317-1321. https://doi.org/10.1093/carcin/17.6.1317

35. Wei J, Xie X, Huang F et al (2020) Simultaneous Microcystis algicidal and microcystin synthesis inhibition by a red pigment prodigiosin. Environ Pollut 256:113444

36. WHO CT (1998) Microcystin-LR, Guidelines for Drinking Water Quality.World Heal Organ Geneva95110

37. WHO G (2011) Guidelines for drinking-water quality. World Heal Organ 216:303-304

38. Zhang D, Xie P, Chen J (2010) Effects of temperature on the stability of microcystins in muscle of fish and its consequences for food safety. Bull Environ Contam Toxicol 84:202-207

39. Zhao S, Yuan C, Tuo X et al (2021) MCLR induces dysregulation of calcium homeostasis and endoplasmic reticulum stress resulting in apoptosis in Sertoli cells. Chemosphere 263:127868

\section{Figures}




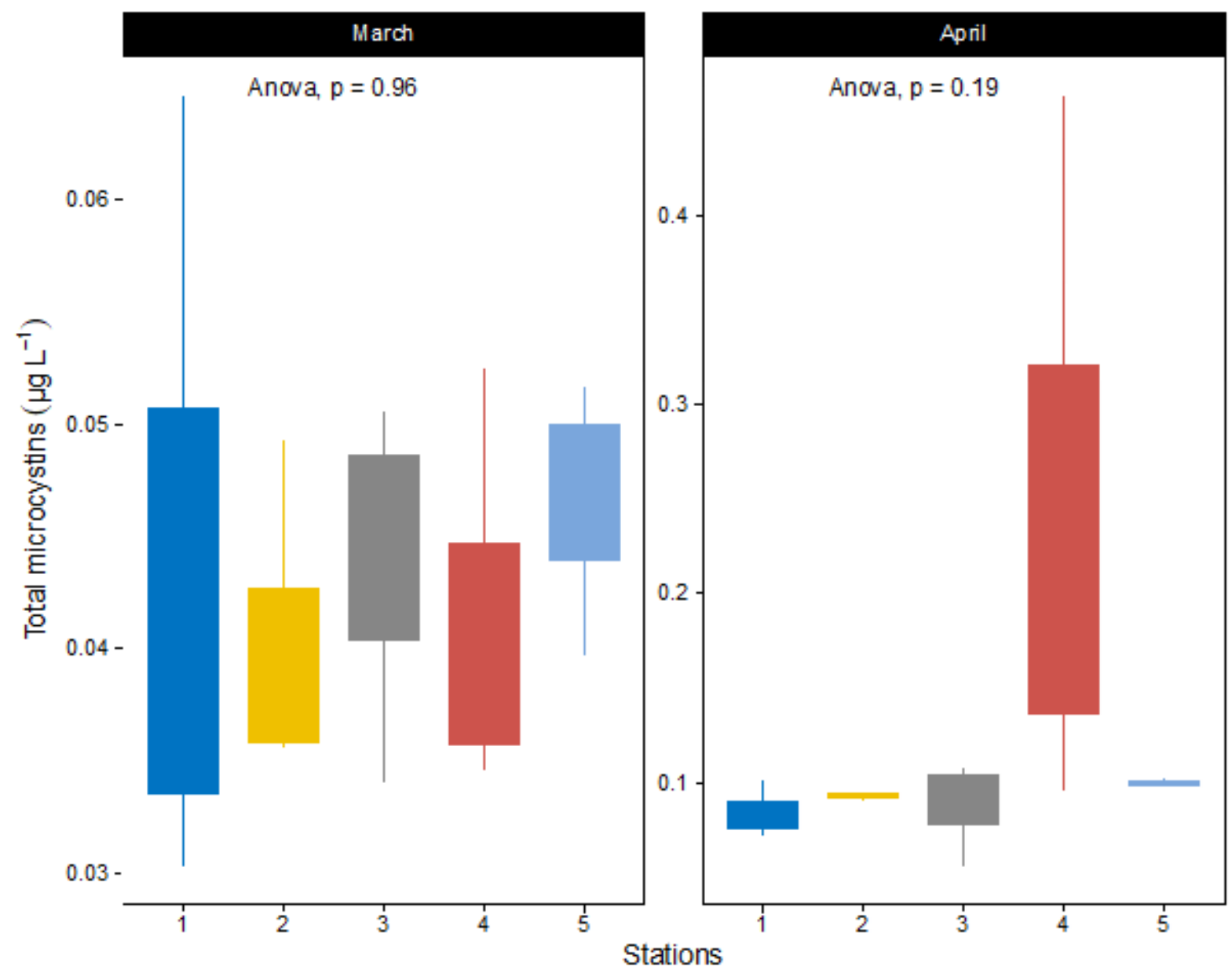

Figure 1

Monthly variation in total microcystins concentrations in Kwaru stream Hayin Danmani, Kaduna, Kaduna state. Values represent mean plus and minus standard deviation for $\mathrm{n}=3$. 


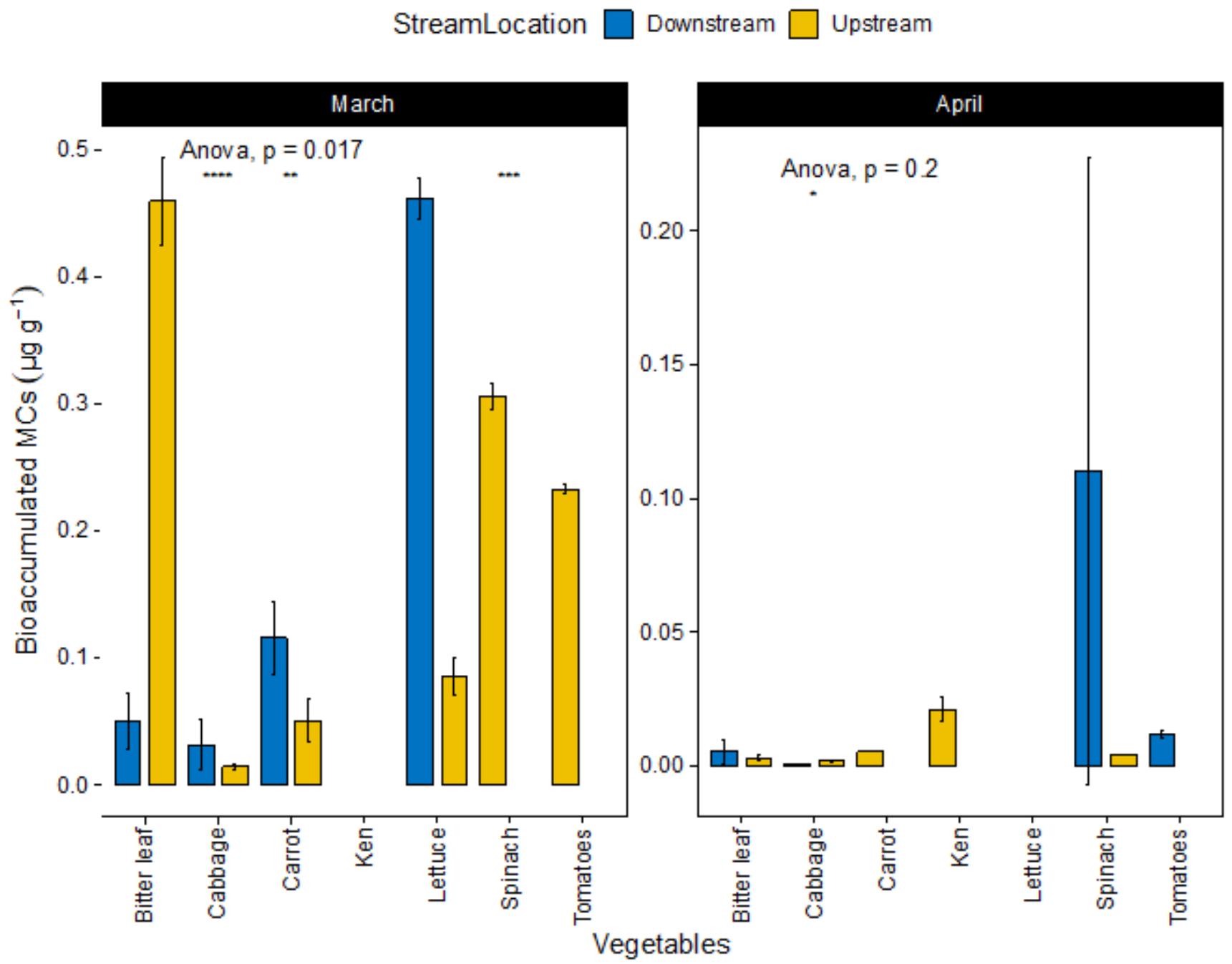

Figure 2

Total microcystins concentration in vegetables from Kwaru stream Hayin Danmani, Kaduna, Kaduna state. Values represent mean plus and minus standard deviation for $n=3$. Values with asterisks are significantly different at $p<0.05$. 
A.
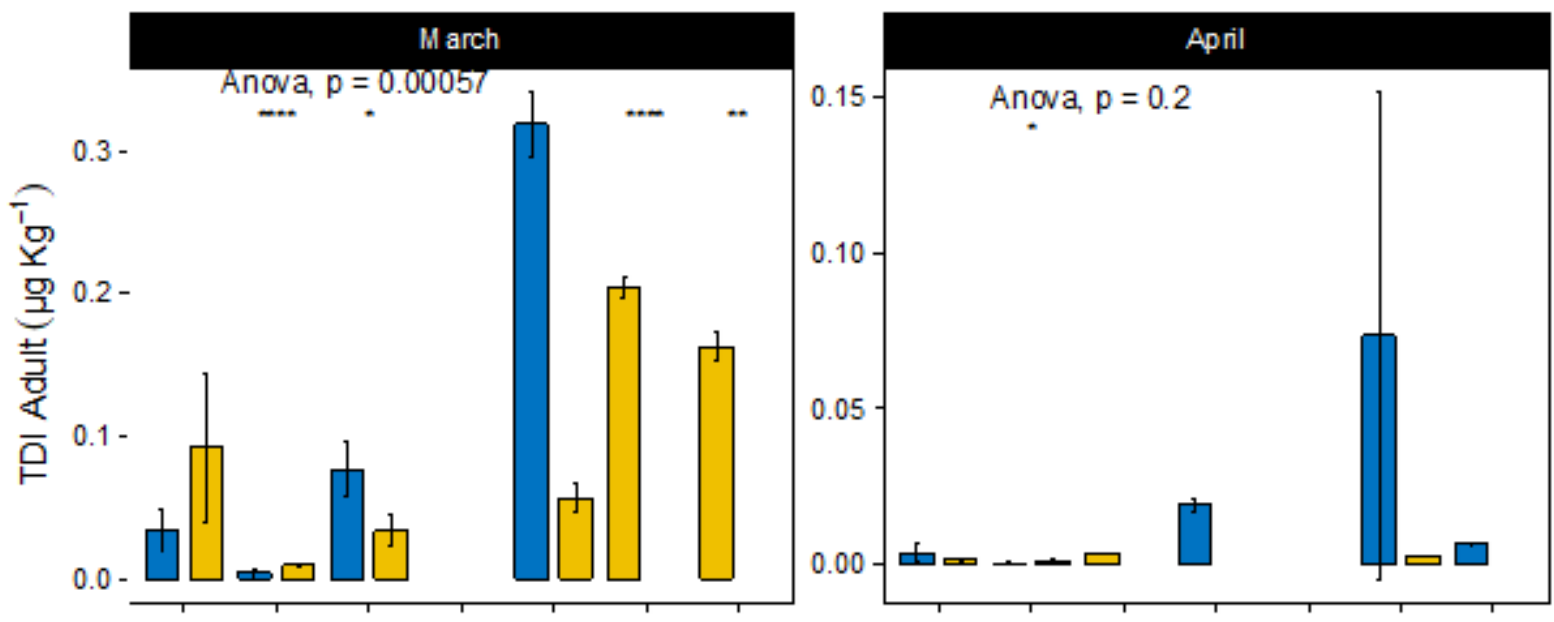

B.
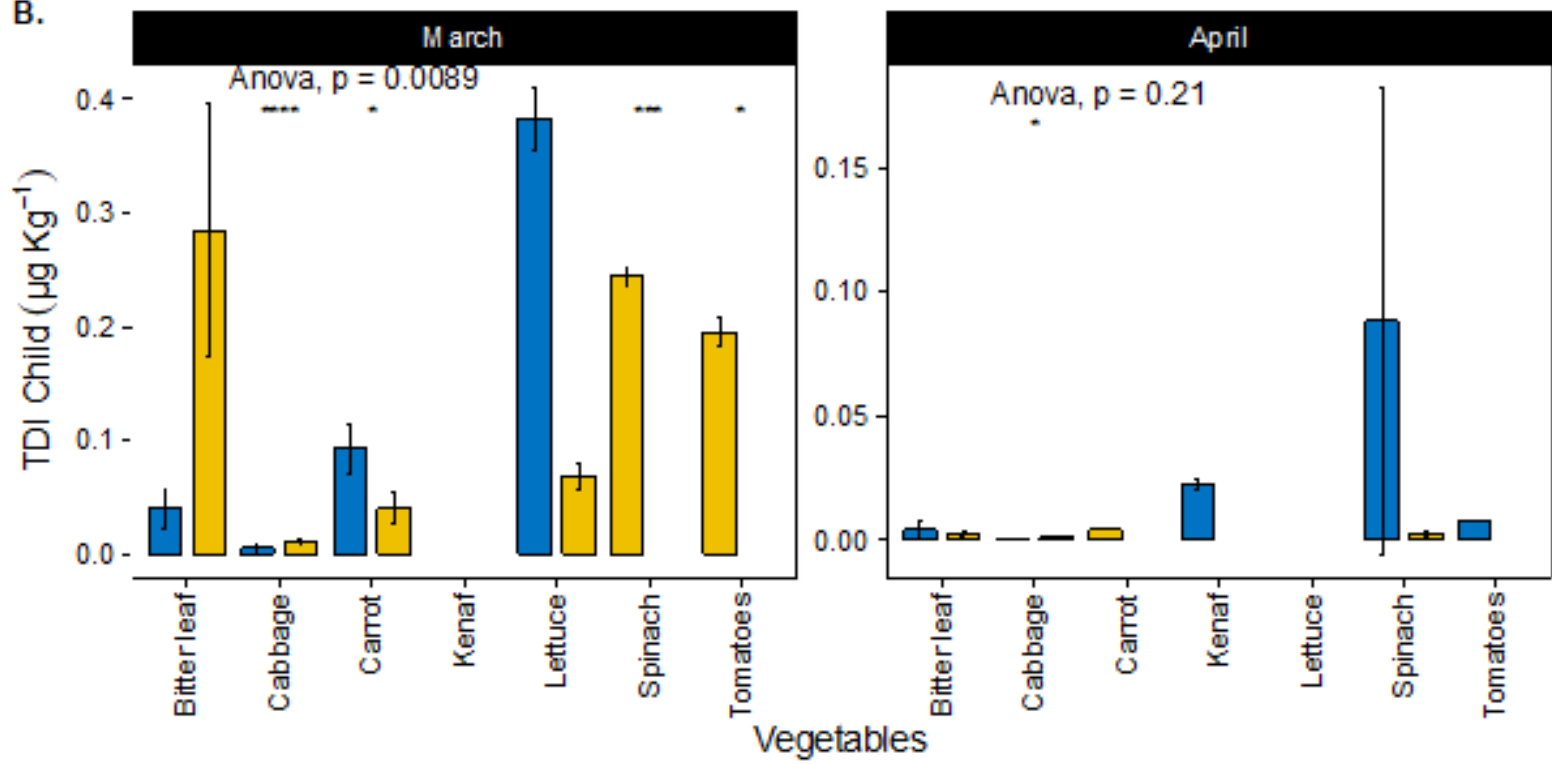

Figure 3

Total daily intake (TDI) of microcystins by an adult and a child following consumption of different vegetables irrigated with contaminated water from Kwaru stream, Kaduna. Values represent mean plus and minus standard deviation for $n=3$. Values with asterisks are significantly different at $p<0.05$ 
A.

Station $-1-2-3-4-5$

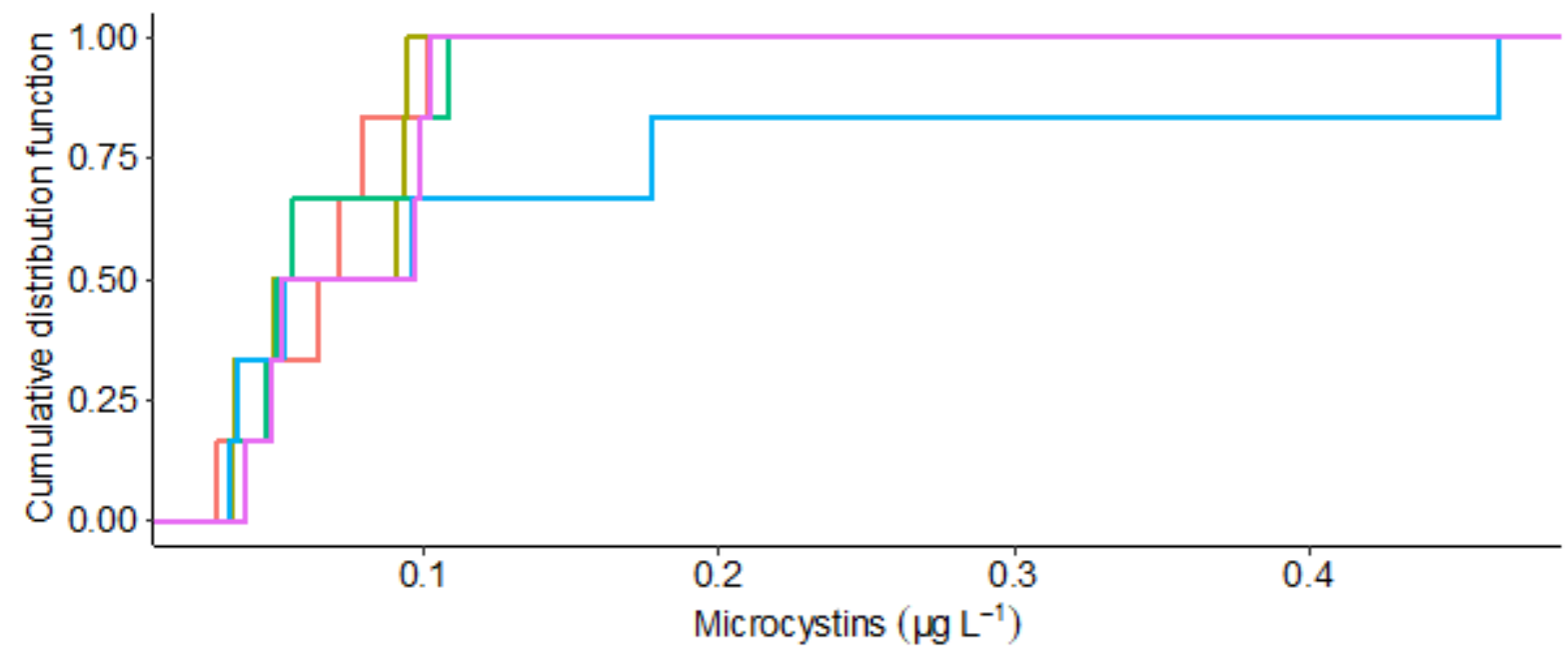

B.

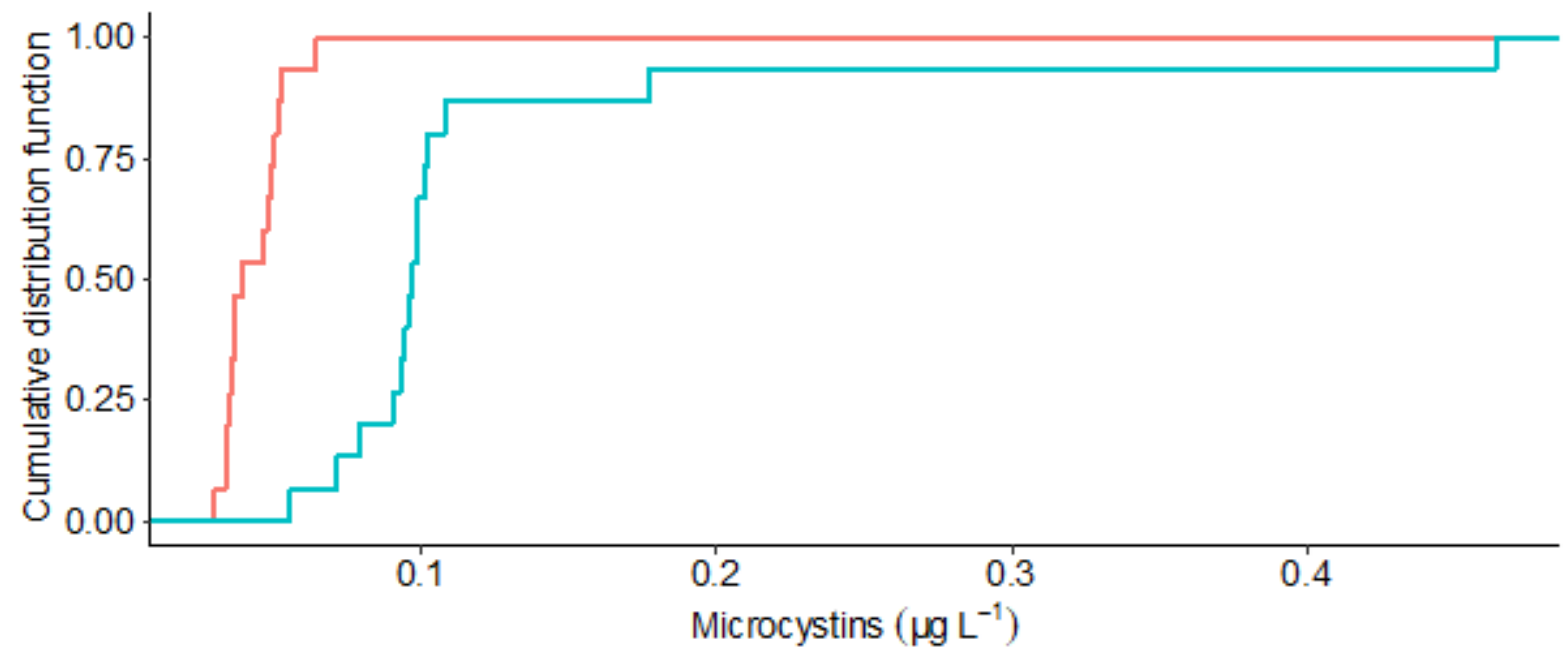

\section{Figure 4}

Monthly and station variation in the estimated cumulative distribution functions (CDF) of mean microcystins content in water collected from Kwaru stream, Kaduna-Nigeria. 
A.

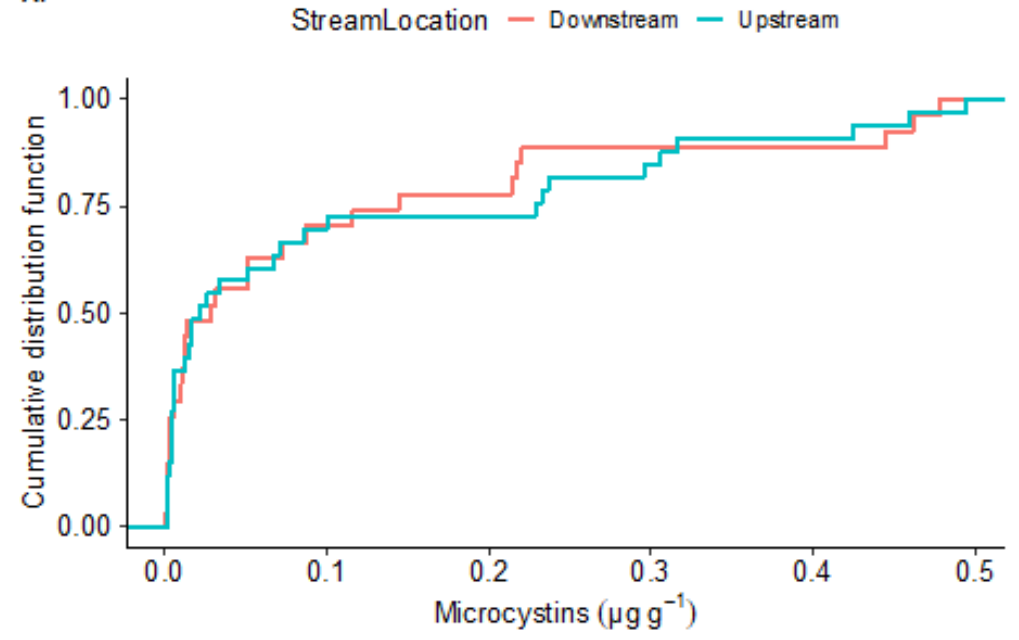

B.

Month - March - April

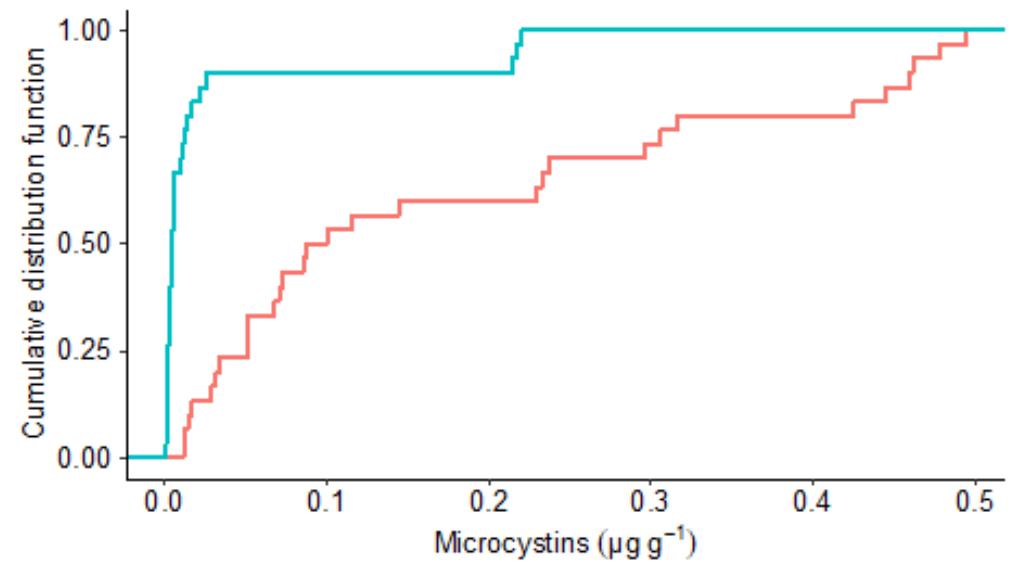

c.

$$
\begin{aligned}
& \text { Vegetable }- \text { Bitter leaf }- \text { Carrot }- \text { Lettuce - Tomatoes } \\
& \text { - Cabbage }- \text { Ken }- \text { Spinach }
\end{aligned}
$$

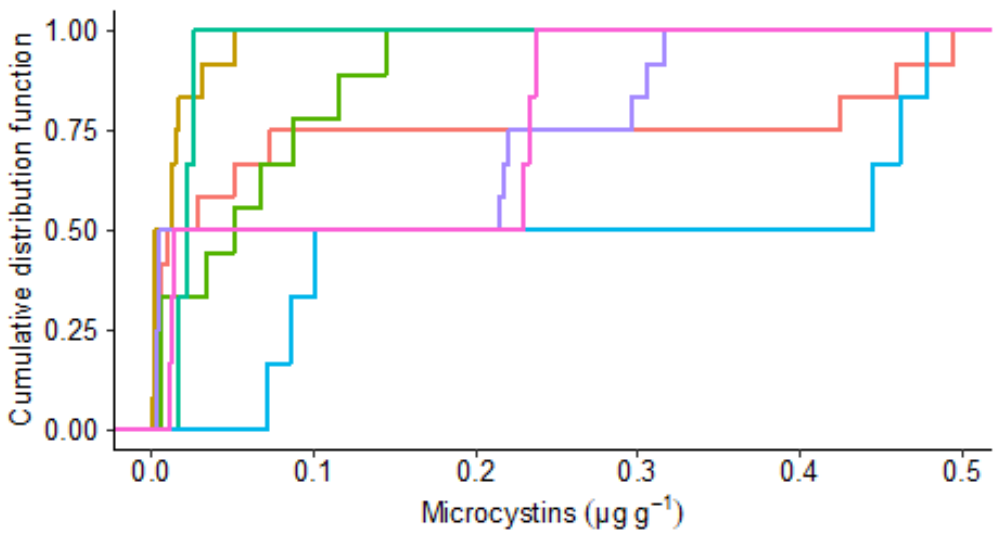

\section{Figure 5}

Monthly, location, and vegetable variation in the estimated cumulative distribution functions (CDF) of mean microcystins content in vegetables irrigated with water from Kwaru stream, Kaduna-Nigeria. 